\title{
Expression of Albumin in Nonhepatic Tissues and its Synthesis by the Bovine Mammary Gland
}

\author{
A. Shamay, ${ }^{1}$ R. Homans, ${ }^{1}$ Y. Fuerman, ${ }^{1}$ I. Levin, ${ }^{2}$ H. Barash, ${ }^{1}$ \\ N. Silanikove, ${ }^{1}$ and S. J. Mabjeesh ${ }^{3}$ \\ ${ }^{1}$ Institute of Animal Science, and \\ ${ }^{2}$ Institute of Garden and Field Crops, Agricultural Research Organization (ARO), \\ Volcani Center, PO Box 6, Bet Dagan, 50250, Israel \\ ${ }^{3}$ Department of Animal Science, Faculty of Agricultural, \\ Food and Environmental Quality Sciences, Faculty of Agriculture, \\ The Hebrew University of Jerusalem, PO Box 12, Rehovot 76100, Israel
}

\section{ABSTRACT}

Albumin is a well-characterized product of the liver. In the present study, objectives were to determine if the albumin gene is also expressed in various nonhepatic tissues in the bovine; whether mammary gland epithelial cells synthesize albumin; and how its synthesis is affected by bovine mastitis. Albumin expression was monitored using reverse transcription-polymerase chain reaction. Tissues examined were: liver, mammary gland, tongue, intestine, lymph gland, testicle, ovary, and uterus. All tissues except the ovary expressed the albumin gene, albeit less so than the liver. The highest level of expression (other than liver) was found in the lymph nodes but expression was also found in the mammary gland. Incubation of mammary gland explants with the labeled amino acid L- $\left[{ }^{35} \mathrm{~S}\right]$ methionine resulted in formation of labeled immunoprecipitable albumin, newly synthesized in the explant. Immunoprecipitable albumin in the medium verified that newly synthesized albumin was also secreted into the medium. This shows that the gland itself is a source of milk albumin. Albumin mRNA expression was approximately 4 times higher in mammary gland tissue from 6 mastitic cows compared with expression in mammary tissue from 6 healthy glands. Further, secretion of albumin was increased 3.5-fold from explants of mastitic mammary glands compared with secretion from explants of healthy mammary glands. Addition of lipopolysaccharide increased the synthesis and secretion of albumin in mammary gland cells in a dose-dependent manner. Exposure to lipopolysaccharide accelerated albumin synthesis in a time-dependent manner up to 48 $\mathrm{h}$. These results lead us to suggest that the secretion of albumin by the mammary gland is part of the innate nonspecific defense system.

Received July 29, 2004

Accepted November 3, 2004

Corresponding author: A. Shamay; e-mail: shamay@agri.huji.ac.il.
(Key words: albumin, mastitis, mammary gland, lipopolysaccharide)

Abbreviation key: FCS = Fetal calf serum, GAPDH = glyceraldehyde-3-phosphate dehydrogenase, RTPCR $=$ reverse transcription-PCR.

\section{INTRODUCTION}

Albumin, a single polypeptide with 585 amino acids with a molecular weight of $\sim 66 \mathrm{kDa}$, is a major plasma protein, responsible for binding and transport of many biologically active molecules (Peters, 1985). Albumin is synthesized largely in the liver, although nonhepatic expression has been documented in several other tissues including mouse retina (Dodson et al., 2001), mouse skeletal muscle (Wagatsuma et al., 2002), human ovarian epithelial cells (Varricchio and Stromberg, 1994), and bovine tracheal gland serous cells (Jacquot et al., 1988). In fetal and newborn kidney, lung, and heart tissue of rats, extrahepatic expression of albumin was higher than in the corresponding adult tissues (Nahon et al., 1988). The extrahepatic production of albumin suggests that the noncolloid-osmotic properties of albumin have a selective advantage (Baker, 1998).

Milk whey albumin has the same amino acid sequence as the blood serum molecule. Therefore, it is commonly believed that albumin enters the milk by leaking through the epithelial tight junction from the systemic fluids (De Wit, 1998). In fact, in many experiments, increase in milk albumin was taken as evidence for tight junction disruption (Nguyen and Nevill, 1998). Albumin concentration in milk increases during functional transitions from lactation to involution and from involution to lactogenesis (Sordillo et al., 1987) and during inflammation (Riollet et al., 2000; Watanabe et al., 2000). During these periods the mammary gland is exposed to high concentrations of free radicals, and albumin may augment the antioxidant defenses of the gland (Bounous, 2000). 
Bovine mastitis is defined as inflammation of the mammary gland; it is caused mainly by bacterial infection. The inflammatory response is caused in many cases because invading pathogens such as Escherichia coli release endotoxin (LPS protein complexes; Riollet et al., 2000; Bradley, 2002), which induces secretion of proinflammatory cytokines, such as tumor necrosis factor- $\alpha$, from epithelial cells and milk leukocytes (Bannerman et al., 2003).

The albumin concentration in milk increases during clinical and subclinical mastitis in cows (Bannerman et al., 2003), sheep (Leitner et al., 2004a), and goats (Leitner et al., 2004b). It has been assumed hitherto that the source of the increase in milk albumin during mastitis is leakage through the tight junction (Bannerman et al., 2003). However, in light of the aforementioned evidence for extrahepatic synthesis of albumin, an alternative explanation is possible: if there were an increase in its glandular expression, synthesis and secretion into the milk, it would be evidence that albumin was a constituent of the innate immune system. Thus, the main objectives of our present study were to determine whether mammary gland epithelial cells synthesize albumin, and how its synthesis is affected by bovine mastitis.

\section{MATERIALS AND METHODS}

\section{Materials}

Media including M-199 and DMEM F-12 (HAM) 1:1 as well as L-glutamine, penicillin, streptomycin, and fungizone (amphotericin B) were obtained from Biological Industries Ltd., Bet Haemek, Israel. Lipopolysaccharide (0111:B4G), insulin, hyaluronidase (type 1-S; $300 \mathrm{U} / \mathrm{mg}$ ), and cortisol were from Sigma (St. Louis, MO). Collagenase (type II; $135 \mathrm{U} / \mathrm{mg}$ ) was obtained from Worthington Biochemical Corp., Freehold, NY. Nitex filters of various sizes were obtained from Tetko Co., Elmsford, NY. Fetal calf serum (FCS) was purchased from Biological Industries Ltd.

\section{In Situ Labeling of Albumin and Immunoprecipitation of Labeled Albumin}

Mammary tissue from a lactating cow was obtained from the slaughterhouse and prepared for isotope labeling as previously described (Yahav et al., 1997). Briefly, mammary gland tissue was cut into small pieces ( 3 to $6 \mathrm{mg}$ ), washed in methionine-free DMEM medium, and placed on impregnated lens paper in a $35-\mathrm{mm}$ Petri dish.

To each dish (containing $1 \mathrm{~mL}$ of medium) was added $50 \mu \mathrm{Ci}$ of $\mathrm{L}-\left[{ }^{35} \mathrm{~S}\right]$ methionine $(1175 \mathrm{Ci} / \mathrm{mmol})$ and the explants were incubated for $6 \mathrm{~h}$ at $37^{\circ} \mathrm{C}$. At the end of incubation the explants were extracted with $50 \mathrm{mM}$ Tris-HCl pH 8.0, $150 \mathrm{~m} M \mathrm{NaCl}, 5 \mathrm{~m} M$ EDTA, 0.5\% Nonidet P-40, $3 \mu \mathrm{g} / \mathrm{mL}$ phenylmethylsulfonyl fluoride, and $1 \%$ aprotonin. After extraction, the lysate was clarified for $10 \mathrm{~min}$ at $10,000 \times \mathrm{g}$. The clear solution was incubated with Protein A-Sepharose CL-4B beads (Pharmacia, Uppsala, Sweden) for $30 \mathrm{~min}$ at $24^{\circ} \mathrm{C}$. The mixture was centrifuged and the supernatant was incubated with rabbit antibovine serum albumin polyclonal antibody 1:20,000 (B1520; Sigma) overnight at $4^{\circ} \mathrm{C}$ followed by binding to Protein A-Sepharose beads for 1.5 $\mathrm{h}$ at $24^{\circ} \mathrm{C}$. The beads were washed twice with $50 \mathrm{mM}$ Tris-HCl pH 7.4, $150 \mathrm{~m} M$ NaCl, $5 \mathrm{~m} M$ EDTA, and 0.5\% Nonidet P-40, and once with the same buffer with 500 $\mathrm{m} M \mathrm{NaCl}$. The pellet of beads was suspended in SDS sample buffer and run on $10 \%$ polyacrylamide gel, which was then exposed to Kodak X-film.

\section{Preparation of Mammary Gland Explants}

Mammary gland tissue from lactating ( 4 mo in lactation), dry ( $>1 \mathrm{mo}$ ), and mastitic cows (as defined by the attending veterinarian) was obtained from the slaughterhouse. The tissue was transferred into medium M199 containing $100 \mathrm{U}$ of penicillin, $100 \mu \mathrm{g}$ of streptomycin, $0.25 \mu \mathrm{g}$ of fungizone, and insulin at $1 \mu \mathrm{g} / \mathrm{mL}$ and transported to the laboratory. Explants were prepared as previously described (Shamay et al., 1987). The mammary gland tissue was cut into small pieces ( 3 to $6 \mathrm{mg}$ ) and placed on an impregnated lens paper in a 50-mm plastic dish. Five milliliters of medium M-199 with $1 \mu \mathrm{g}$ of insulin, 10,000 $\mathrm{U}$ of penicillin, $10 \mu \mathrm{g}$ of streptomycin, $0.025 \mathrm{mg}$ of fungizone, and $0.5 \mu \mathrm{g}$ cortisol/ $\mathrm{mL}$ and different concentrations of LPS were added. The mammary gland explants were cultured at $37^{\circ} \mathrm{C}$ in the medium in $5 \% \quad \mathrm{CO}_{2} / 95 \%$ air atmosphere. The medium was changed every $24 \mathrm{~h}$ for $3 \mathrm{~d}$. Albumin secretion to the medium was determined by ELISA assay.

\section{Preparation of Primary Culture}

Bovine mammary gland tissue was transferred to the laboratory, cut into small pieces and placed in a 500mL Erlenmeyer flask containing M-199 supplemented with collagenase $(1 \mathrm{mg} / \mathrm{mL})$, hyaluronidase $(1 \mathrm{mg} / \mathrm{mL})$, and bovine insulin $(1 \mu \mathrm{g} / \mathrm{mL})$ in a ratio of $10 \mathrm{~mL}$ of medium to $1 \mathrm{~g}$ of tissue. The culture was swirled on a gyratory water bath at $100 \mathrm{rpm}$ and $37^{\circ} \mathrm{C}$ for 3 to 4 $\mathrm{h}$. During this period, tissue fragments were further dissociated by occasional aspiration through a $10-\mathrm{mL}$ pipette with a large orifice. One hour before termination of the enzymatic digestion, $0.04 \%$ DNase was added at $0.5 \mathrm{~mL}$ per $100 \mathrm{~mL}$ of digest. At the end of the incubation, the suspension was passed through a Nitex filter 
$(200 \mu \mathrm{m})$ and the cells were washed 3 to 5 times with M-199. The cells were grown in a $10-\mathrm{mm}$ plastic dish in DMEM F-12 (HAM) 1:1, supplemented with $10 \%$ FCS, $1 \mu \mathrm{g}$ of insulin, 10,000 $\mathrm{U}$ of penicillin, $10 \mathrm{mg}$ of streptomycin, $0.025 \mathrm{mg}$ of fungizone, and $0.5 \mathrm{mg}$ of Lglutamine $/ \mathrm{mL}$ in a humidified atmosphere of $5 \% \mathrm{CO}_{2} /$ $95 \%$ air at $37^{\circ} \mathrm{C}$. The medium was changed at $48-\mathrm{h}$ intervals until the start of an experiment. The cells were grown to confluency, dispersed with $0.05 \%$ trypsin, and transferred to other plates. Cells were stored at $-70^{\circ} \mathrm{C}$ in $10 \%$ DMSO and $20 \%$ FCS. The cells used in these experiments had undergone 6 or fewer transfers. Once the experiment started, the cells received the same medium but without FCS and with different concentrations of LPS. The cells were used for RNA isolation. Albumin secretion to the medium was determined by ELISA assay.

\section{RNA Isolation}

Total RNA was isolated from the various tissues or from mammary gland epithelial cells by means of the guanidinium thiocyanate procedure as described by Chomczynski and Sacchi (1987). The RNA concentration was determined by absorbance at $260 \mathrm{~nm}$. Upon isolation, RNA was frozen at $-70^{\circ} \mathrm{C}$ pending analysis by reverse transcription-PCR (RT-PCR) or real time RT-PCR.

\section{RT-PCR Assay}

Reverse transcription-PCR was performed on total RNA preparations from the various tissues, using an EZ-first strand cDNA synthesis kit for RT-PCR (Biological Industries Ltd.). Kit control RNA was human total RNA and primer mix was human glyceraldehyde-3phosphate dehydrogenase (GAPDH) amplimers. Two micrograms of total RNA was added to $40 \mu M$ Oligo(dT) primer and diethyl pyrocarbonate (DEPC)-treated water in a total volume of $10 \mu \mathrm{L}$, and the mixture was heated at $70^{\circ} \mathrm{C}$ for $10 \mathrm{~min}$. This step was followed by the addition of $8 \mu \mathrm{L}$ of $2.5 \times$ reaction mix and $100 \mathrm{mM}$ dithiothreitol to a total volume of $20 \mu \mathrm{L}$. The reaction tubes were incubated at $42^{\circ} \mathrm{C}$ for $60 \mathrm{~min}$. Following this step, the tubes were heated at $70^{\circ} \mathrm{C}$ for $15 \mathrm{~min}$.

For PCR amplification of the various tissues, the reaction mixture was diluted to a final volume of $100 \mu \mathrm{L}$. Five microliters of the diluted cDNA was added to 50 $\mu \mathrm{L}$ of PCR reaction mixture (5 $\mu \mathrm{L}$ of $10 \times$ PCR buffer, $1 \mu \mathrm{L}$ of dNTP, $1 \mu \mathrm{L}$ of Taq DNA polymerase, $2 \mu \mathrm{L}$ of forward primer, and $2 \mu \mathrm{L}$ of reverse primer). The primer sequences for albumin were: 5' TTC CTT CGT GAA ACC TAT GG 3' (forward) and 5' GCA GCA TTC CTT GTG GAC TT 3' (reverse).
The amplification parameters for the BSA gene were initial denaturation at $94^{\circ} \mathrm{C}$ for $2 \mathrm{~min}, 35$ cycles of denaturation at $94^{\circ} \mathrm{C}$ for $45 \mathrm{~s}$, annealing at $56^{\circ} \mathrm{C}$ for $45 \mathrm{~s}$, and extension at $72^{\circ} \mathrm{C}$ for $2 \mathrm{~min}$. There was a final extension at $72^{\circ} \mathrm{C}$ for $7 \mathrm{~min}$. To verify that equal amounts of RNA were analyzed, cDNA was tested by RT-PCR for the expression of the housekeeping gene GAPDH mRNA. The primer sequences for GAPDH were: $5^{\prime}$ TCC ACC ACC CTG TTG CTG TA 3' (forward) and 5' TGT TCC AGT ATG ATT CCA CCC 3' (reverse).

The amplification parameters for the GAPDH gene were the same as for albumin. The expected product sizes were as follows: albumin, $501 \mathrm{bp}$ : GAPDH, 850 bp. Polymerase chain reaction products were size-separated by electrophoresis on $1 \%$ agarose gels. The gels were stained with ethidium bromide.

\section{Real Time RT-PCR Assay}

Real time RT-PCR for albumin mRNA was carried out with forward (5' AGG GAG GTC TGG GCT ATC ATC $\left.3^{\prime}\right)$ and reverse (5' TTC GTG AAA CCT ATG GTG ACA TG $3^{\prime}$ ) primers employing a SYBR green measurement of the accumulation of double-stranded DNA. As a normalizing control, GAPDH primers (forward 5' TTG ACT GTG CCG TTG AAC TTG 3' and reverse 5' TTC TGG CAA AGT GGA CAT CGT $3^{\prime}$ ) or $18 \mathrm{~S}$ primers (forward 5' CGG CTA CCA CAT CCA AGG AA $3^{\prime}$ and reverse 5' GGG CCT CGA AAG AGT CCT GT 3') were used. A Eurogentec qPCR Mastermix for SYBR Green I kit and the appropriate protocol were used to prepare the various samples to a total volume of $20 \mu \mathrm{L}: 10 \mu \mathrm{L}$ of $2 \times$ reaction buffer, $1 \mu \mathrm{L}$ of forward primer ( $100 \mathrm{pmol})$, $1 \mu \mathrm{L}$ of reverse primer (100 pmol), $4.4 \mu \mathrm{L}$ of deionized water, $0.6 \mu \mathrm{L}$ of SYBR green I stock diluted 1/2000 and $3 \mu \mathrm{L}$ of template (cDNA). An ABI Prism 7700 Sequence Detection System (Applied Biosystems, Foster City, CA) was used: 40 cycles of 1 min of denaturation at $95^{\circ} \mathrm{C}, 2 \mathrm{~min}$ of annealing at $60^{\circ} \mathrm{C}$, and $1 \mathrm{~min}$ of extension at $72^{\circ} \mathrm{C}$. Real-time RT-PCR analysis was performed by the ${ }^{\Delta{ }^{\Delta}} \mathrm{C}_{\mathrm{T}}$ method (delta delta $\mathrm{C}_{\mathrm{T}}$ method); $\mathrm{C}_{\mathrm{T}}$ is the threshold cycle, i.e., the PCR cycle in which an increase in reporter fluorescence above a baseline signal can first be detected. The proportional change detected in mRNA is calculated as $2^{\Delta \Delta} \mathrm{C}_{\mathrm{T}}$ :

$$
\begin{gathered}
{ }^{\Delta \Delta} \mathrm{C}_{\mathrm{T}}=\left(\mathrm{C}_{\mathrm{T} \text { assayed gene: treated }}-\mathrm{C}_{\mathrm{T} \text { GAPDH: treated }}\right) \\
-\left(\mathrm{C}_{\mathrm{T} \text { assayed gene: control }}-\mathrm{C}_{\mathrm{T}} \text { GAPDH: control }\right) .
\end{gathered}
$$

The subscripts refer to the mRNA of the amplified gene and whether the sample was experimental or a control. 


\section{ELISA Assay}

Analysis of BSA was done as described by Stelwagen et al. (1994). Enzyme linked immunosorbent assay was performed on medium collected from tissue cultures of healthy, mastitic, and dry mammary gland tissue explants and on medium collected from primary culture cells, with or without LPS. The ELISA was carried out in two 96-well polystyrene microtiter plates, referred to as the mixing plate and the ELISA plate. One hundred microliters of coating solution $(10 \mu \mathrm{g} / \mathrm{mL}$ of BSA in 0.1 $M$ carbonate buffer, $\mathrm{pH}$ 9.6) was added to each well of the ELISA plate, and the plate was incubated for $2 \mathrm{~h}$ at $37^{\circ} \mathrm{C}$ followed by an overnight incubation at $4^{\circ} \mathrm{C}$. The wells were then washed 3 times with $1 \times \mathrm{PBS}(\mathrm{pH} 7.4$ containing $0.05 \%$ Tween 20 ), and $200 \mu \mathrm{L}$ of ELISA diluent $(0.1 \%$ polyvinylpyrrolidone prepared in $1 \times \mathrm{PBS}, \mathrm{pH}$ 7.4, containing $0.05 \%$ Tween 20) was added as a blocking agent. Following an overnight incubation at $37^{\circ} \mathrm{C}$, the wells were washed as described previously. In the wells of the mixing plate, $100 \mu \mathrm{L}$ of BSA standard and medium samples were incubated overnight at $37^{\circ} \mathrm{C}$ with $100 \mu \mathrm{L}$ of mouse monoclonal antibovine serum (B201; Sigma) at a final dilution of 1:8000 in ELISA diluent. After incubation, $100 \mu \mathrm{L}$ of the mixture from the mixing plate wells were added to the ELISA plate, which was incubated for $1.5 \mathrm{~h}$ at $37^{\circ} \mathrm{C}$. Wells of the ELISA plate were washed as described previously and incubated with $100 \mu \mathrm{L}$ of goat antimouse IgG peroxidase conjugate (Sigma) at a final dilution of 1:2500 in ELISA diluent for $1.5 \mathrm{~h}$ at $37^{\circ} \mathrm{C}$. Following incubation, the wells of the ELISA plate were washed 3 times as described previously, after which $100 \mu \mathrm{L}$ of substrate solution (0.1\% 2' 2'-azino-diethylbenzo-thiazoline in citrate-phosphate buffer, $\mathrm{pH} 4.0$, containing $0.003 \%$ (wt/ vol) $\mathrm{H}_{2} \mathrm{O}_{2}$ ) were added to each well. After a final incubation at $20^{\circ} \mathrm{C}$ for $30 \mathrm{~min}$, absorbance was measured at $405 \mathrm{~nm}$. The standard BSA curve range was 20 to 800 ng; intra- and interassay coefficients of variation were less than $8 \%$.

\section{Statistical Analyses}

One-way ANOVA was carried out with the JMP Statistical Discovery software (SAS Institute Inc., Cary, NC). The main effects differed among the different experiments; they included sources of mammary gland tissue, lipopolysaccharide concentrations, and incubation lengths. Means were separated by Student's $t$-test and differences were considered significant when $P<$ 0.05 .

The statistical analysis of the real-time RT-PCR was performed according to Livak and Schmittgen (2001). Dennett's $t$-test was used to compare multiple results

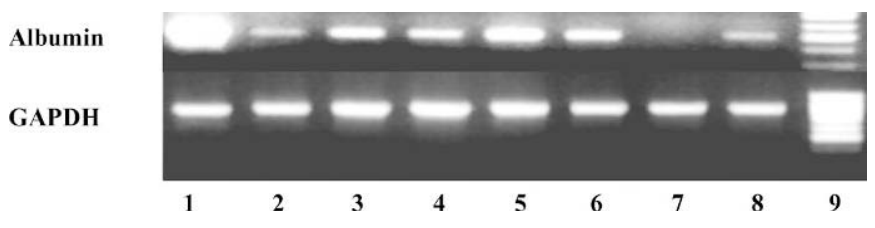

Figure 1. Expression of albumin in bovine peripheral tissues. Albumin expression in various tissues of a cow was monitored by reverse transcription-PCR (RT-PCR). The tissues examined were: liver (lane 1), mammary gland (lane 2), tongue (lane 3), intestine (lane 4), lymph gland (lane 5), testicle (lane 6), ovary (lane 7), uterus (lane 8), 100-bp ladder (lane 9). The lower panel shows the glyceraldehyde-3-phosphate dehydrogenase (GAPDH) reference housekeeping gene. Figure represents data from 3 RT-PCR from 3 cows.

with a single control. Significance was declared at $P$ $<0.05$.

\section{RESULTS}

\section{Extrahepatic Expression of Albumin mRNA in Peripheral Tissues}

Figure 1 shows the RT-PCR of albumin mRNA from nonhepatic tissues and from liver tissue. A band of the albumin mRNA derived from liver total RNA was of the expected size (lane 1). We detected RT-PCR products from some of the nonhepatic samples that were of the same size as the product from the liver tissue (lanes 2 to 6 and 8). The expression of GAPDH was similar in all tissues.

\section{De Novo Synthesis of Albumin in the Mammary Gland}

Incubation of the explants with the labeled amino acid $\mathrm{L}_{\mathrm{L}}\left[{ }^{35} \mathrm{~S}\right]$ methionine resulted in the formation of labeled immunoprecipitable albumin, indicating that it was newly synthesized in the explant. The presence of immunoprecipitable albumin in the medium indicates that the newly synthesized albumin was also secreted into the medium. A band corresponding to $66 \mathrm{kDa}$ is visible. Immunoprecipitation of the lysate with albumin antibodies (lane 2 in Figure 2A, marked $\mathrm{TH}+$ ) reveals a single visible band at $66 \mathrm{kDa}$. Increasing the ratio of the lysate to the antibodies increased the expression of the immunoprecipitated albumin, as expected (lane 1 in Figure 2B, marked TH+). This ratio between sample and antibodies also demonstrates the secretion of immunoprecipitable albumin in the medium (lane 2 in Figure 2B, marked $\mathrm{M}+$ ). Under these conditions, some unspecific binding of 2 proteins with molecular weights $>100 \mathrm{kDa}$ is seen (Figure 2B); these probably relate to impurities among the commercial albumin antibodies. 
A

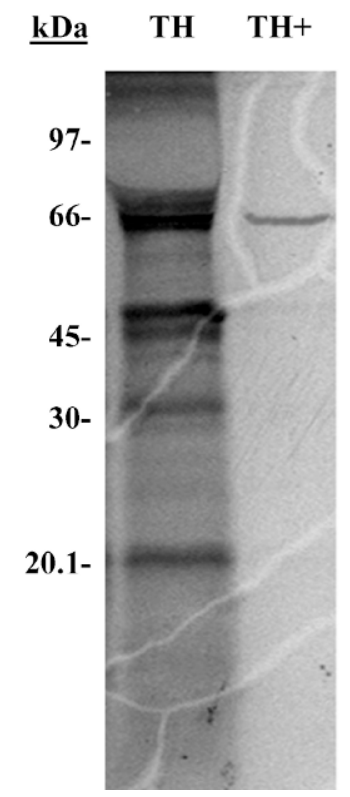

B

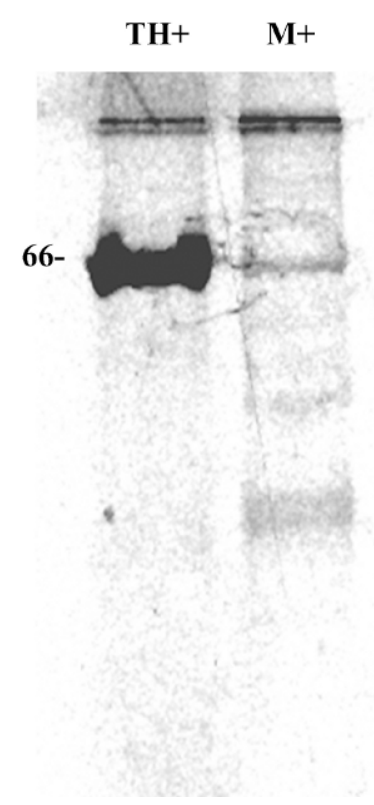

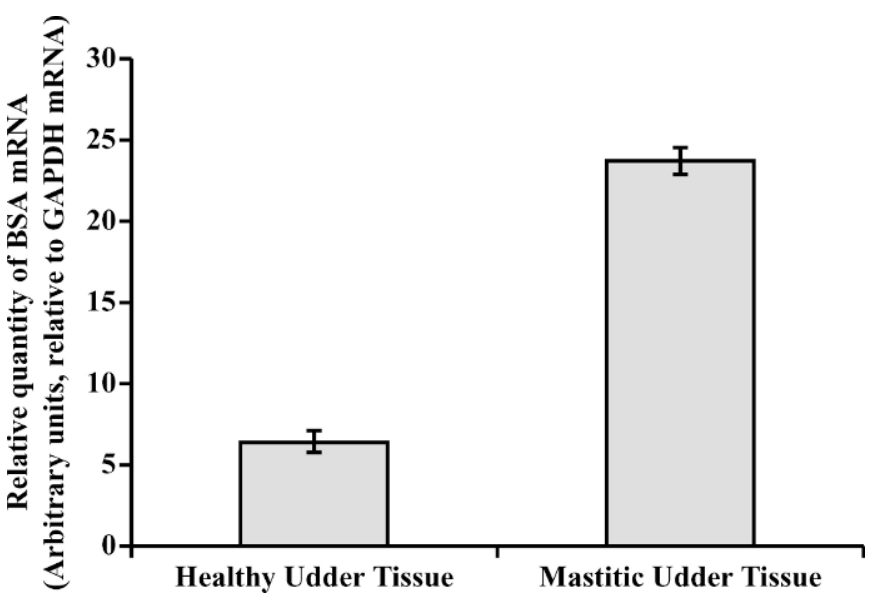

Figure 3. Expression of albumin mRNA in mammary gland explants from healthy and mastitic dairy cow tissue. Mammary gland tissues from 6 healthy and 6 mastitic dairy cows were analyzed for albumin mRNA expression. Albumin expression was measured by real-time reverse transcription-PCR. Results are mean $\pm \mathrm{SE}(\mathrm{n}=6$, $P<0.05$ ).

was examined by means of real-time RT-PCR, and albumin secretion was measured by ELISA. The results showed that LPS had a significant dose-dependent effect on the expression of albumin mRNA (Figure 5) and on the secretion of albumin from mammary gland cells (Figure 6).

\section{Effect of LPS on Synthesis of Albumin in the Mammary Gland of a Dairy Cow}

Mammary gland explants from a healthy lactating dairy cow were incubated in medium containing LPS

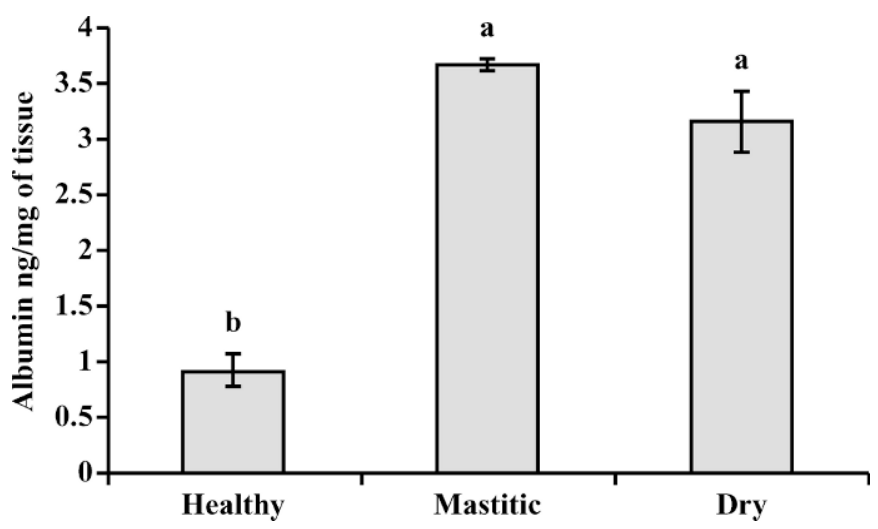

Figure 4. Secretion of albumin from mammary gland explants from healthy, mastitic, and dry dairy cow tissue into the medium. The explants were incubated for $3 \mathrm{~d}$ in medium, and albumin secretion from the explants to the medium was measured by ELISA. Results are mean $\pm \mathrm{SE}\left(\mathrm{n}=9\right.$ dishes). ${ }^{\mathrm{a}, \mathrm{b}}$ Different letters indicate statistically significant differences between means $(P<0.05)$. 


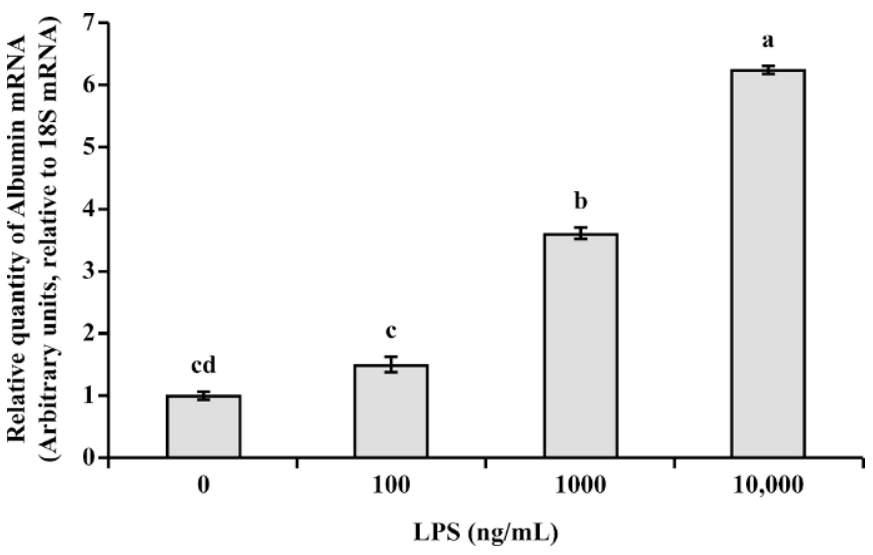

Figure 5. Expression of albumin mRNA in primary culture mammary gland cells after exposure to LPS. The cells were incubated for $48 \mathrm{~h}$ in medium containing LPS at $0,100,1000$, or $10,000 \mathrm{ng} / \mathrm{mL}$ in 10 $\mathrm{mm}$ dishes. Albumin expression was measured by real-time reverse transcription-PCR in RNA prepared from the cells. Results are mean $\pm \mathrm{SE}\left(\mathrm{n}=6\right.$ dishes). ${ }^{\mathrm{a}, \mathrm{b}, \mathrm{c}, \mathrm{d}}$ Different letters indicate statistically significant differences between means $(P<0.05)$.

(100 ng/mL) for 24, 48, and $72 \mathrm{~h}$. Albumin expression was examined by real-time RT-PCR. Lipopolysaccharide augmented the expression of albumin mRNA for $48 \mathrm{~h}$ (Figure 7), but there was a decline in the expression of albumin mRNA after $72 \mathrm{~h}$, probably because of degeneration of the explants.

\section{DISCUSSION}

In the present study, we demonstrated the extrahepatic expression of albumin mRNA in bovine peripheral

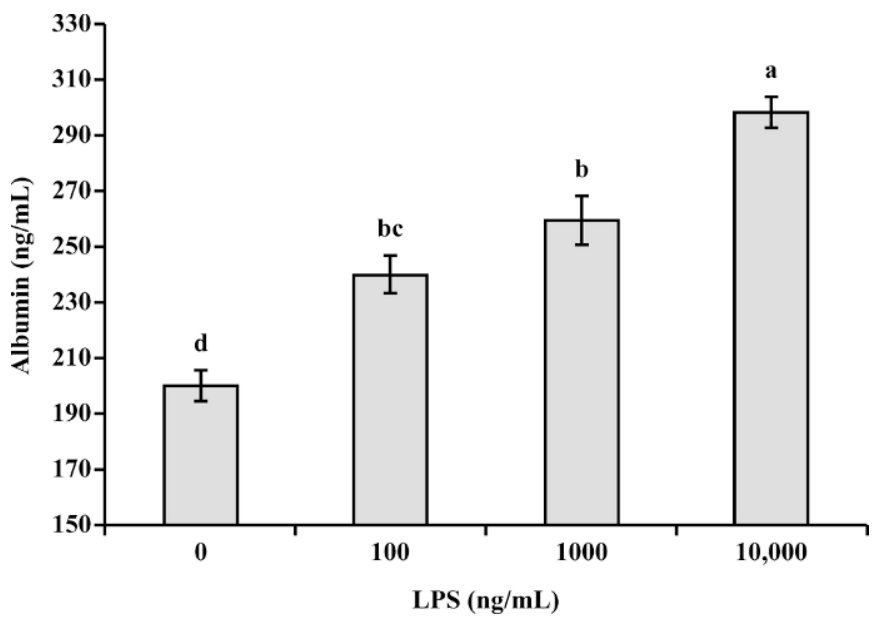

Figure 6. Secretion of albumin from primary culture mammary gland cells after exposure to LPS. The cells were incubated for $72 \mathrm{~h}$ in medium containing LPS at $0,100,1000$, or $10,000 \mathrm{ng} / \mathrm{mL}$. Albumin secretion was measured by ELISA. Results are mean $\pm \mathrm{SE}(\mathrm{n}=6$ dishes). ${ }^{a, b, c, d}$ Different letters indicate statistically significant differences between means $(P<0.05)$.

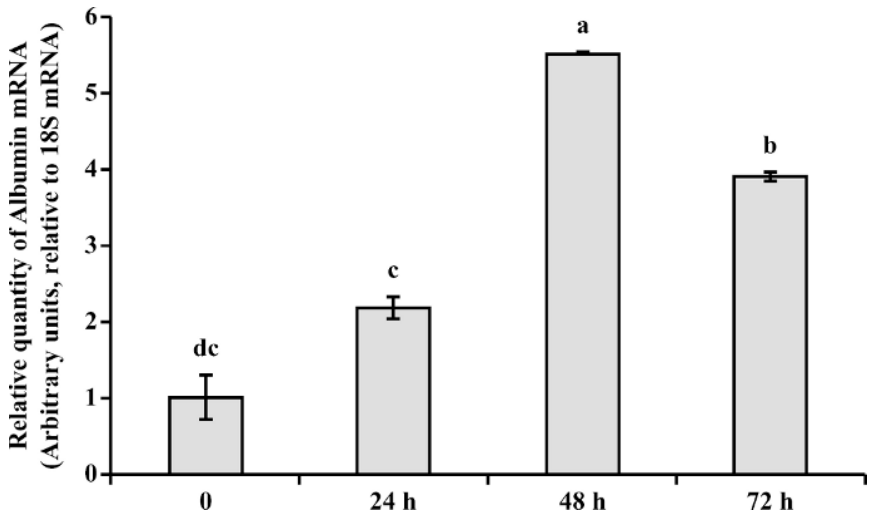

Figure 7. Expression of albumin mRNA in mammary gland tissue explants exposed to LPS. The explants were incubated for 24,48 , or $72 \mathrm{~h}$ in $50-\mathrm{mm}$ dishes in medium containing LPS at $100 \mathrm{ng} / \mathrm{mL}$. Explants were harvested after each time point and albumin expression was measured by real-time reverse transcription-PCR. Results are mean $\pm \mathrm{SE}$ ( $\mathrm{n}=6$ dishes). ${ }^{\mathrm{a}, \mathrm{b}, \mathrm{c}, \mathrm{d}}$ Different letters indicate statistically significant differences between means $(P<0.05)$.

tissues. Apart from the liver, the highest expression of albumin was found in lymph tissue (Figure 1). In addition, we demonstrated that mammary gland cells contain the information needed to synthesize albumin from amino acid precursors and to secrete the synthesized albumin into the medium (Figure 2).

It was generally thought that the main site of albumin synthesis is in the liver, and that the albumin enters the milk from the blood stream via a tight junction (De Wit, 1998). Phillippy and McCarthy (1979) addressed this question by injecting ${ }^{14} \mathrm{C}$ leucine into the teat canal of goats and found the radioactivity in serum albumin isolated from the milk. In the present study we established that mammary gland cells synthesize and secrete albumin, a finding that is consistent with previous evidence for extrahepatic synthesis of albumin in various tissues, at a number of development stages, in several mammalian species (Jacquot et al., 1988; Nahon et al., 1988; Varricchio and Stromberg, 1994; Dodson et al., 2001; Wagatsuma et al., 2001, 2002). We do not, however, exclude the possibility that some of the milk albumin is derived from the interstitial fluid.

In general, components of the mammary gland innate system, such as immunoglobulin type A and lactoferrin are constantly secreted into the milk. Their concentration, however, increases markedly following bacterial invasion and during involution and colostrum secretion (Hurley, 1989; Hagiwara et al., 2003). The marked increases in expression, synthesis, and secretion of albumin in mastitic animals strongly suggest that a major source for the increase in the content of albumin in milk under inflammatory conditions is the gland itself. 
In keeping with the behavior of other components of the innate system, we found that expression and synthesis of albumin in dry cows were considerably higher than in lactating cows (Figure 4).

To pinpoint the interrelationships among inflammatory response, albumin synthesis, and secretion we studied how exposure to $E$. coli LPS affected these measures in explants of healthy tissue and in mammary gland epithelial cells. The dose and time dependence of the responses are evidence of the regulatory response at the glandular level. However, the mechanism by which LPS induces regulatory responses in gland expression, and synthesis and secretion of albumin is yet to be elucidated. Fox et al. (1981) found that albumin concentration was significantly greater in mammary gland quarters that had been injected with LPS than in uninjected controls. Injecting casein hydrolyzates into mammary gland quarters of cows induced similar responses in albumin secretion in the injected and control glands (Shamay et al., 2003). In the latter case, it was shown that the tight junction of the control glands remained intact; therefore, leakage of albumin cannot explain the increase in albumin concentration. Induction of proinflammatory cytokine secretion from mammary epithelial cells in response to stimulation with LPS or casein hydrolyzates may explain the response in the control glands. In support of this hypothesis, it was shown that intramammary infusion of tumor necrosis factor- $\alpha$ increased the concentration of albumin in the milk of the treated cows (Watanabe et al., 2000).

Further research is needed to reveal the role that albumin plays in the mammary gland defense system. However, available information on albumin biochemical characteristic reveals exciting potential: because albumin has an affinity for lipophilic compounds, it may serve as a sink for toxins, such as lipopolysaccharides, and lipophilic mutagens.

\section{CONCLUSIONS}

Conclusive evidence is presented that albumin is expressed and synthesized by the mammary gland, and secreted into the medium, and by inference, secreted into milk. These components of albumin metabolism are augmented in response to LPS that mimics inflammatory conditions, which suggests that albumin is part of the mammary gland innate immune system.

\section{ACKNOWLEDGMENTS}

The authors thank G. Brener, D. Hochman, and A. Tomer for their help at the Marbek Company's slaughterhouse, the Cattle Breeders' Association of Israel for its support, and S. Ovadia and K. Ovadia for comprehensive discussions.

\section{REFERENCES}

M. E. 1998. Albumin's role in steroid hormone action and the origins of vertebrates: Is albumin an essential protein? FEBS Lett. 439:9-12.

Bannerman, D. D., M. J. Paape, W. R. Hare, and E. J. Sohn. 2003. Increased levels of LPS-binding protein in bovine blood and milk following bacterial lipopolysaccharide challenge. J. Dairy Sci. 86:3128-3137.

Bounous, G. 2000. Whey protein concentrate (WPC) and glutathione modulation in cancer treatment. Anticancer Res. 20:4785-4792.

Bradley, A. J. 2002. Bovine mastitis: An evolving disease. Vet. J. 164:116-128.

Chomczynski, P., and N. Sacchi. 1987. Single-step method of RNA isolation by acid guanidinium thiocyanate-phenol-chloroform extraction. Anal. Biochem. 162:156-159.

De Wit, J. N. 1998. Nutritional and functional characteristics of whey proteins in food products. J. Dairy Sci. 81:597-608.

Dodson, C. S., K. Rengarajan, H. D. Gewant, E. Stodulkova, H. T. Nguyen, J. H. Boatright, and J. M. Nickerson. 2001. Extra-hepatic expression of serum albumin mRNA in mouse retina. Curr. Eye Res. 22:182-189.

Fox, L. K., C. W. Heald, F. C. Gwazdauskas, and W. E. Vinson. 1981. Concentrations of glucocorticoids, bovine serum albumin and somatic cells in mastitic milk. J. Dairy Sci. 64:2258-2261.

Hagiwara, S., K. Kawai, A. Anri, and H. Nagahata. 2003. Lactoferrin concentrations in milk from normal and subclinical mastitic cows. J. Vet. Med. Sci. 65:319-323.

Hurley, W. L. 1989. Mammary gland functions during involution. J. Dairy Sci. 72:1637-1646.

Jacquot, J., G. Goldstein, C. Sommerhoff, R. Benali, E. Puchelle, and C. B. Basbaum. 1988. Synthesis and secretion of an albumin-like protein by cultured bovine tracheal gland serous cells. Biochem. Biophys. Res. Commun. 15:857-862.

Leitner, G., M. Chaffer, A. Shamay, F. Shapiro, U. Merin, E. Ezra, A. Saran, and N. Silanikove. 2004a. Changes in milk composition as affected by subclinical mastitis in sheep. J. Dairy Sci. 87:46-52.

Leitner, G., U. Merin, and N. Silanikove. 2004b. Changes in milk composition as affected by subclinical mastitis in goats. J. Dairy Sci. 87:1719-1726.

Livak, K. J., and T. D. Schmittgen. 2001. Analysis of relative gene expression data using real-time quantitative PCR and the 2(Delta Delta C(T)) method. Methods 25:402-408.

Nahon, J. L., I. Tratner, A. Poliard, F. Presse, M. Poiret, A. Gal, J. M. Sala-Trepat, L. Legres, G. Feldmann, and D. Bernunau. 1988. Albumin and $\alpha$-fetoprotein gene expression in various nonhepatic rat tissues. J. Biol. Chem. 263:11436-11442.

Nguyen, D. A. D., and M. C. Nevill. 1998. Tight junction regulation in the mammary gland. J. Mammary Gland Biol. Neoplasia 3:233-246.

Peters, T. 1985. Serum albumin. Adv. Protein Chem. 37:161-236.

Phillippy, O. B., and R. D. McCarthy. 1979. Multi-origins of milk serum albumin in the lactating goat. Biochim. Biophys. Acta 548:298-303.

Riollet, C., P. Rainard, and B. Poutrel. 2000. Differential induction of complement fragment C5a and inflammatory cytokines during intramammary infections with Escherichia coli and Staphylococcus aureus. Clin. Diagn. Lab. Immunol. 7:161-167.

Shamay, A., F. Shapiro, G. Leitner, and N. Silanikove. 2003. Infusions of casein hydrolyzates into the mammary gland disrupt tight junction integrity and induce involution in cows. J. Dairy Sci. $86: 1250-1258$.

Shamay, A., E. Zeelon, Z. Ghez, N. Cohen, A. G. Mackinlay, and A. Gertler. 1987. Inhibition of casein and fat synthesis and $\alpha$ lactalbumin secretion by progesterone in explants from bovine lactating mammary glands. J. Endocrinol. 113:81-88. 
Sordillo, L. M., S. C. Nickerson, R. M. Akers, and S. P. Oliver. 1987. Secretion composition during bovine mammary involution and the relationship with mastitis. Int. J. Biochem. 19:1165-1172.

Stelwagen, K., S. R. Davis, V. C. Farr, S. J. Eichle, and I. Politis. 1994. Effect of once milking and concurrent somatotropin on mammary tight junction permeability and yield of cows. J. Dairy Sci. 77:2994-3001.

Varricchio, F., and K. Stromberg. 1994. An albumin-like protein is the major secretory protein of ovarian epithelial cells in vivo and in vitro. J. Gynecol. Cancer 4:328-332.

Wagatsuma, A., K. Fujimoto, and S. Yamada. 2002. Alteration in albumin level during modified muscular activity. Scand. J. Med. Sci. Sports 12:143-149.
Wagatsuma, A., Y. Yamazaki, K. Mizuno, and S. Yamada. 2001. Molecular properties and gene expression of albumin in the skeletal muscle following hindlimb immobilization in a shortened position. Acta Neuropathol. 10:540-546.

Watanabe, A., Y. Yagi, H. Shiono, and Y. Yokomizo. 2000. Effect of intramammary infusion of tumour necrosis factor- $\alpha$ on milk protein composition and induction of acute-phase protein in the lactating cow. J. Vet. Med. 47:653-662.

Yahav, S., A. Shamay, G. Horev, D. Bar-Ilan, O. Genina, and M. Friedman-Einat. 1997. Effect of acquisition of improved thermotolerance on the induction of heat shock proteins in broiler chickens. Poult. Sci. 76:1428-1434. 